\title{
How Comfortable are Malaysian Users in Utilizing Webpages of Small Businesses?
}

\author{
By Moha Asri Abdullah \\ MD Fardous Alom ${ }^{\prime}$ \\ Nurita Juhdit \\ Noorihsan Mohammad ${ }^{\circ}$ \\ Muhammad-Bashir Owolabi Yusuf \\ S. M. Ferdous Azam*
}

The main objective of the current study is to explore the challenges the Malaysian consumers face in terms of e-commerce experiences with small businesses in general. In addition, the study looks into the potential impacts of demographic profiles of respondents on the e-commerce experiences in general and bad experiences in particular. The results suggest that e-commerce users face highest challenges with after purchase services followed by overall quality, usage experience, value, and installation. Regarding bad experiences, slow internet appears on the top of the list followed by slow delivery of the products, unfriendly website, poor quality products, complicated payment system, and unsecured operations. Also, this study reveals that security issue is no longer serious issue for Malaysian customers. The demographic characteristics have significant impacts on the level of satisfaction perceived in the e-commerce transaction while regarding bad experiences the demographic profiles have little or no impacts.

Keywords: E-Commerce, Experiences, Malaysia, Small and medium businesses

\section{Introduction}

The use of electronic commerce (e-commerce) facilities for business and individual purposes is becoming routine works worldwide due to the rapid development of internet (Khatibi et al. 2003). The exponential growth of internet provided opportunity to the people to interact culturally, communicate effectively, acquire knowledge and do businesses in general and in particular it provided promising facilities to the e-commerce, a trade that takes place over the internet (Goldstein and O'connor 2000). By the dawn of twenty first century, the government of Malaysia has recognized the internet technology as the key driver of new economy. On this premise, Malaysia's third long-term plan has emphasized that the contemporary Information Communications Technology (ICT) as the key enabler of society, economy and politics. As of June 2012, the number of internet users in Malaysia is 17,723,000 or $60.7 \%$ of

\footnotetext{
*Professor, Department of Economics, International Islamic University Malaysia, Malaysia.

$\dagger$ Assistant Professor, Department of Economics, International Islamic University Malaysia, Malaysia.

\#Assistant Professor, Department of Business Administration, International Islamic University Malaysia, Malaysia.

Assistant Professor, Department of Economics, International Islamic University Malaysia, Malaysia.

'Post Doctoral Researcher, Department of Economics, International Islamic University Malaysia, Malaysia.

*PhD Candidate, Department of Business Administration, International Islamic University Malaysia, Malaysia.
} 
the total population of Malaysia are involved with ICT activities using internet facilities and it is forecasted that the number will reach at 25 million by the end of 2017 (Internet World Stats 2014).

More specifically in Malaysia, there is a group trend on the use of ecommerce in small business. Beside the business practitioners, the academicians are also measuring experience of users in utilizing e-commerce of small business these days because of its rapid growth. Despite registering spectacular growth, the major challenge remains with small business, where the e-commerce adoption is still not that expected as other sectors do (Shah Alam et al. 2011). To complement this, research into perceptions of e-commerce transaction has started to be expanded.

The objective of the current study is to investigate the challenges of Malaysian users of e-commerce usually experience while having transaction. This research additionally looks into the possible impacts of demographic profiles of respondents on the e-commerce experiences that can be effective for the policy makers and practitioners in the long run.

\section{Review of the Literature}

Consumers'perceptions of e-commerce keep changing over time with the advancement of IT facilities. There are many factors that affect the adoption procedures of e-commerce such as overall quality of online transaction, product quality, product delivery, internet services, security and privacy, payment system (Abbad et al. 2011, Corbitt et al. 2003, Dillon and Reif 2004, Udo 2001).

For the small business transactions, consumers usually look over the service quality of online shopping. Essentially, the first thing that an online customer takes into consideration is website quality. However, there are a variety of approaches for measuring website quality (Liao et al. 2006). Key dimensions investigated for website quality include: design, content, entertainment, usability, reliability, interactivity, security, and privacy.

Most of the extant research focus on developing ways to measure perceived website quality in terms of e-commerce transaction. Overall quality of e-service is very important for the online customers (Santos 2003). Low price and just web presence is not enough to prevent failure of e-commerce rather e-service quality is much more important (Wang 2003). If the overall quality that may include system quality, information quality and service quality of the e-commerce improves, expedition of e-commerce adoption occurs (Lin 2007). Some work report on relevant operational attributes associated with using a website (Bauer and Scharl 2000), while others assess users evaluations of extensive lists of specific website attributes (Olsina et al. 2001). Furthermore, researches focus on the technical quality of the website (Aladwani and Palvia 2002, Liu and Arnett 2002, Loiacono et al. 2002, Ranganathan and Ganapathy 2002).

Alternatively, website quality in terms of the service quality provided to consumers is also focused (Zeithaml et al. 1996). Potter (1994) recommends focusing on a more limited set of website factors and attributes related to users' 
broader perceptions of website characteristics. Features of the user interface, such as site design and ease of useare found to affect service quality perception and satisfaction (Dabholkar 1996, Meuter et al. 2000, Zeithaml et al. 1996). Mathwick et al. (2001) identify experiential factors such as playfulness and aesthetics as being important elements in the assessment of customer value in catalog and internet shopping environments. Thus, it is clear that quality of the website, internet system, speed of internet, services related to purchase, delivery, installation and after purchase service are the important things that create the positive perceptions of users toward e-commerce transaction.

The security and privacy issue is a considerable factor because it comprises a lot of personal details including bank account number or credit card numbers. Security and privacy emerged as the main impediment of ecommerce transaction (Abbad et al. 2011, Udo 2001). If proper security is not ensured and maintained, the consumers' perception on e-commerce transaction must fall down. Insufficient trust and securityof individuals and organizations is one of the important barrier of using internet for business purposes (Turban et al. 2009, Van Slyke et al. 2003). Trust is considered to be one of the important factors for e-commerce adoption from customer's point of view where trust level is likely influenced by the level of perceived market orientation, site quality, technical trust-worthiness and users' web experiences (Corbitt et al. 2003).

Above discussions shed light on the various factors that affect e-commerce adoption in different perspectives. Few studies have been conducted on ecommerce in the context of Malaysia from either business' or users' perspectives. Mukti (2000) reports that security concern is the main barrier of e-commerce adoption for businesses along with some other concerns such as uncertainty regarding contractual and financial issues.

Paynter and Lim (2001) indicate, in a study conducted in the context of Malaysian online shopping, that security is the main impediment for online shopping along with lack of information technology (IT) knowledge, vendor reputation problem, customers' attitude problem, payment options, personal computer cost, preference for physical examination of the products and price of the products. Another study conducted by Khatibi et al. (2003) in the context of Malaysian businesses also report that security and privacy, stringent requirements of technological skills and weariness of the rules and regulations are the major barriers of e-commerce adoption.

However, the current study is distinct from existing studies in several ways: first, there is a dearth of study conducted on the perceptions of ecommerce users' in the context of Malaysia; second, most of the current studies are conducted from the business' point of view to identify the barriers of e-commerce adoption while this study looks into the issue from users point of view; third, the current study utilizes recently collected information on the perceptions of e-commerce users to reflect the ever changing pace of perceptions with the rapid expansion of internet facilities; and finally, the study focuses more on the adverse experiences the users face in using e-commerce facilities to identify the most adverse experience they encounter with. 


\section{Data and Methodology}

The objective of the current study is to explore the challenges the Malaysian consumers face during e-transactions. In order to reveal main challenges, a questionnaire approach is adopted in this study. The questionnaire used in this study is composed of three main sections. The first section gives an overview of the proposed research, the second section contains demographic information of the respondents including gender, ethnicity, and the third section consists of questions regarding the experiences of e-commerce use. The sampling frame for conducting the analysis comprises 600 Malaysian consumers taken from different places of Kuala Lumpur. A purposive sampling technique of homogeneous sampling has been employed with a criteria such as the survey targetted only those respondents who use small businesses's websites to buy products and are willing to share their experiences.

A survey instrument in the form of a structured questionnaire has been designed using scales established in academic and managerial literature regarding the aspects. The items in the survey questionnaire are selected from the variables deemed to be pertinent as gleaned from the literature and from interviews of academic and other professionals. The questionnaire consists of a few general questions as regards the competitive business environment, geographical differences and complying with demographic information. A 5-point Liker scale is used ranging from "strongly disagree" to "strongly agree" used in the study.

Survey questioners are selected as the major method for data collection as it appears to be a strong preference to collect data for e-commercetransaction concerns and issues with usage and satisfaction level. For collecting the data, a survey papers were distributed to the selected 600 people with the consent letter with an official letterhead from the Faculty of Economics and Management Sciences of International Islamic University Malaysia (IIUM) to explain the purpose of the gathering information. Out of 600 survey questionnaires 525 responses were returned back and 21 of the responses were incomplete. Thus the valid responses are 504.

The reliability and dimensionality of information and scale are checked with Cronbach's alpha and exploratory factor analysis respectively. To analyze data method of descriptive statistics such as frequency, arithmetic means, standard deviations (SD), ratios; and a multiple regression and one-way analysis of variance (ANOVA) are used.

\section{Sample Information}

Table 1 summarizes demographic information obtained in the survey. Majority of the respondents are female consisting of $61.8 \%$ while male counterpart is only $38.1 \%$. Concerning race Malay represents $74.2 \%$ followed by others $(18.8 \%)$, Indian $4.0 \%$ and Chinese $3.0 \%$. Monthly income the respondents' shows that $61.6 \%$ have income less than RM 2,000, $24.3 \%$ have income in between RM 2,000 and 3,000 while around 11\% of the respondents are earning more than RM 3,000 per month. Annual frequency of purchase by using e-commerce facilities represents that $88.4 \%$ bought products less than 10 times and only $11.6 \%$ bought more than 10 times in a year. Annual expenditure 
on the purchase using e-commerce facilities indicates that $76.9 \%$ respondents spent less than RM 1,000, 11.4\% spent in between RM 1,000 and RM 1,500 and only $11.6 \%$ spent more than RM 1,500 .

Table 1. Summary of Demographic Information

\begin{tabular}{|l|c|}
\hline Variable & $\%$ \\
\hline Gender & 38.1 \\
\hline Male & 61.8 \\
\hline Female & \\
\hline Race & 74.2 \\
\hline Malay & 4.0 \\
\hline Indian & 3.0 \\
\hline Chinese & 18.8 \\
\hline Others & \\
\hline Level of income (RM per month) & 61.6 \\
\hline$<2,000$ & 24.3 \\
\hline $2,000-3,999$ & 5.7 \\
\hline $4,000-5,999$ & 2.8 \\
\hline $6,000-7,999$ & 3.8 \\
\hline $8,000-9,999$ & 1.9 \\
\hline$>10,000$ & \\
\hline Annual purchase of products using e-commerce (Times) & 65.6 \\
\hline$<5$ & 22.8 \\
\hline $5-9$ & 7.0 \\
\hline $10-14$ & 4.5 \\
\hline$>=15$ & \\
\hline Annual expenses on purchases using e-commerce (RM) & 51.6 \\
\hline$<500$ & 25.3 \\
\hline $500-999$ & 11.4 \\
\hline $1,000-1,499$ & 2.7 \\
\hline $1,500-1,999$ & 2.4 \\
\hline $2,000-2,499$ & 2.2 \\
\hline $2,500-2,999$ & 4.3 \\
\hline$>=3,000$ & \\
\hline$S 001 c:$ Aus & \\
\hline
\end{tabular}

Source: Author's Fieldwork Survey Data 2014.

\section{Results and Discussion}

Before proceeding with the analysis, reliability and dimensionality were checked with Cronbach's alpha and exploratory factor analysis. Overall Cronbach's alpha for e-commerce experience components is 0.889 and for bad experience components is 0.649 . High values of alpha indicate that the scales are reliable. Exploratory factor analysis, as shown in Table 2, reveals that for the set of experience related questions the Eigenvalue for the first component is 3.87 followed by next highest value 0.64 . On the other hand, $64.5 \%$ variance is explained by the first component followed by $10.7 \%$ by the second component. For the set of bad experience related questions the Eigenvalue for the first 
component is 2.39 followed by second component 1.11 . In this case $29.93 \%$ variance is explained by first components while $13.95 \%$ is explained by second component. The first component's high Eigen value and higher percentage of total variance explained by it indicates that the scales are unidimensional.

Table 2. Results of Exploratory Factor Analysis

\begin{tabular}{|c|c|c|c|c|c|c|}
\hline \multirow{3}{*}{ Component } & \multicolumn{6}{|c|}{ Initial Eigenvalues } \\
\hline & \multicolumn{2}{|c|}{ Total } & \multicolumn{2}{|c|}{ \% of Variance } & \multicolumn{2}{|c|}{ Cumulative \% } \\
\hline & Experience & $\begin{array}{c}\text { Bad } \\
\text { experience }\end{array}$ & Experience & $\begin{array}{c}\text { Bad } \\
\text { experience }\end{array}$ & Experience & $\begin{array}{c}\text { Bad } \\
\text { experience }\end{array}$ \\
\hline 1 & 3.870 & 2.395 & 64.505 & 29.932 & 64.505 & 29.932 \\
\hline 2 & 0.642 & 1.117 & 10.705 & 13.958 & 75.210 & 43.890 \\
\hline 3 & 0.478 & 1.032 & 7.970 & 12.900 & 83.180 & 56.790 \\
\hline 4 & 0.410 & 0.943 & 6.828 & 11.786 & 90.008 & 68.575 \\
\hline 5 & 0.316 & 0.794 & 5.267 & 9.927 & 95.275 & 78.502 \\
\hline 6 & 0.284 & 0.771 & 4.725 & 9.638 & 100.000 & 88.139 \\
\hline 7 & & 0.663 & & 8.282 & & 96.421 \\
\hline 8 & & 0.286 & & 3.579 & & 100.000 \\
\hline
\end{tabular}

Source: Author's Fieldwork Survey Data 2014.

Regarding the question of e-commerce experiences for all five components (overall quality, value, purchase experience, installation experience and after purchase experiences), the majority respondents answered that they are somewhat satisfied with e-transactions followed by second majority very satisfied. Table 3 shows that in terms of overall quality of e-transactions $44.6 \%$ of respondents are somewhat satisfied, $39.2 \%$ are very satisfied while $7 \%$ are delightfully satisfied and $6.6 \%$ are somehow and $2.6 \%$ are miserably experienced with e-transactions with small businesses. In terms of value, $41.8 \%$ are somewhat satisfied, $39.8 \%$ are very satisfied, $5.8 \%$ are delightfully satisfied while $8.6 \%$ are somehow and only $1.0 \%$ had miserable experiences. In terms of purchase experience, $80 \%(40+40)$ respondents are somewhat and very satisfied, $5.8 \%$ are delightfully satisfied while $8.6 \%$ are somehow and $2.8 \%$ had miserable experience with e-transaction. Concerning installation or first use experiences, $39.6 \%$ are somewhat, $36.9 \%$ are very and $7.0 \%$ are delightfully satisfied while $9.4 \%$ are somehow and $2.8 \%$ got miserable experiences with e-transaction. With respect to usage experience, $41.2 \%$ are somewhat, $38.4 \%$ are very and $8.2 \%$ are delightfully satisfied while $9.4 \%$ are somehow and $2.8 \%$ are miserably experienced with e-commerce transactions. Same trend follows in the after purchase experiences: $38.4 \%$ are somehow, $33.9 \%$ are very and $6.2 \%$ are delightfully satisfied while $15.7 \%$ are somehow and $5.8 \%$ had miserable experiences with e-commerce transactions. Overall information reveals that about $21.5 \%$ customers experienced relatively bad practices with after purchase services while these percentages are lower in other experience components. Last row of Table 3 shows mean values regarding experience components. It can be viewed that mean scores are above 
three (mid points); mean for purchase experience is the highest (3.43) followed by overall quality (3.41), usage experience (3.40), value (3.38), installation experience (3.31), and after purchase experience (3.19). Mean information also reveals that customers are less satisfied with after purchase experiences while more satisfied with purchase experience.

Table 3. Responses on E-commerce Experience

\begin{tabular}{|l|c|c|c|c|c|c|}
\hline & $\begin{array}{c}\text { Overall } \\
\text { quality }\end{array}$ & Value & $\begin{array}{c}\text { Purchase } \\
\text { experience }\end{array}$ & $\begin{array}{c}\text { Installation } \\
\text { experience }\end{array}$ & $\begin{array}{c}\text { Usage } \\
\text { experience }\end{array}$ & $\begin{array}{c}\text { After } \\
\text { purchase } \\
\text { experience }\end{array}$ \\
\hline Miserable & 2.6 & 1.0 & 2.8 & 2.8 & 2.8 & 5.8 \\
\hline Somehow & 6.6 & 11.6 & 8.6 & 13.7 & 9.4 & 15.7 \\
\hline $\begin{array}{l}\text { Somewhat } \\
\text { satisfactory }\end{array}$ & 44.6 & 41.8 & 40.0 & 39.6 & 41.2 & 38.4 \\
\hline $\begin{array}{l}\text { Very } \\
\text { satisfactory }\end{array}$ & 39.2 & 39.8 & 40.0 & 36.9 & 38.4 & 33.9 \\
\hline Delightful & 7 & 5.8 & 8.6 & 7.0 & 8.2 & 6.2 \\
\hline Mean & 3.41 & 3.38 & 3.43 & 3.31 & 3.40 & 3.19 \\
\hline SD & 0.82 & 0.80 & 0.87 & 0.89 & 0.87 & 0.97 \\
\hline
\end{tabular}

Source: Author's Fieldwork Survey Data 2014.

In view of the question whether the respondents faced any bad experiences with e-commerce transaction, 170 respondents or $34.2 \%$ replied that they did not have any bad experience with e-commerce while majority of respondents totaled 327 or $65.8 \%$ had bad experiences with e-commerce transactions. A subsidiary question was then asked to the positive respondents what type of bad experience they faced with e-commerce. Potential challenges/problems such as slow internet, slow delivery, unfriendly website, complicated payment system, poor quality of products, unsecured operations were identified and asked to answer. Table 4 exhibits that although majority of the respondents have had bad experiences with e-commerce transaction, a minority of the respondents agreed with the provided problems. With regards to slow internet $33.8 \%$ respondents had bad experiences while $66.2 \%$ had no problem with slow internet. It can be viewed that for each bad experience indicators only less than $50 \%$ respondents had encountered bad experiences. The results show that although security and trust is one of the significant limitations as indicated in the literature (Abbad et al. 2011), it is not a big challenge for Malaysian customers. Only $9.9 \%$ customers responded that they had bad experiences with security issues. If the challenges, Malaysian customers face, are ranked slow internet appears on the top of the list followed by slow delivery of the products, unfriendly website, poor quality products, complicated payment system, unsecured operations, and other potential issues. 
Table 4. Responses of Bad Experiences on E-Commerce Transaction

\begin{tabular}{|l|c|c|c|c|c|c|c|}
\hline & $\begin{array}{c}\text { Slow } \\
\text { internet }\end{array}$ & $\begin{array}{c}\text { Slow } \\
\text { delivery }\end{array}$ & $\begin{array}{c}\text { Unfriendly } \\
\text { website }\end{array}$ & $\begin{array}{c}\text { Complicated } \\
\text { payment } \\
\text { method }\end{array}$ & $\begin{array}{c}\text { Poor } \\
\text { quality } \\
\text { product }\end{array}$ & $\begin{array}{c}\text { Unsecured } \\
\text { operations }\end{array}$ & Others \\
\hline $\begin{array}{l}\text { Yes } \\
(\%)\end{array}$ & 33.8 & 25.6 & 25.4 & 19.1 & 20.7 & 9.9 & 3.4 \\
\hline $\begin{array}{l}\text { No } \\
(\%)\end{array}$ & 66.2 & 74.4 & 74.6 & 81.9 & 79.3 & 90.1 & 96.6 \\
\hline Mean & 0.34 & 0.26 & 0.25 & 0.19 & 0.21 & 0.10 & 0.03 \\
\hline SD & 0.48 & 0.44 & 0.44 & 0.39 & 0.41 & 0.30 & 0.18 \\
\hline
\end{tabular}

Source: Author's Fieldwork Survey Data 2014.

In order to supplement these descriptive statistical results we ran a multiple regression where bad experience is the dependent variable and different indicators of bad experiences including slow internet, slow delivery, unfriendly website, complicated payment system, poor quality products, and unsecured operations as dependent variables.

Table 5. Regression Results for Bad Experiences Faced by Malaysian Customers

\begin{tabular}{|l|c|c|}
\hline Coefficients & $\begin{array}{c}\text { Value } \\
\text { (S. error) }\end{array}$ & VIF \\
\hline Constant & $\begin{array}{c}0.273^{* * *} \\
(10.294)\end{array}$ & \\
\hline Slow internet & $\begin{array}{c}0.373^{* * *} \\
(9.255)\end{array}$ & 1.093 \\
\hline Slow delivery & $\begin{array}{c}0.257^{* * *} \\
(6.362)\end{array}$ & 1.097 \\
\hline Unfriendly website & $\begin{array}{c}0.182^{* * *} \\
(5.282)\end{array}$ & 1.103 \\
\hline Complicated payment system & $\begin{array}{c}0.213^{* * *} \\
(5.678)\end{array}$ & 1.096 \\
\hline Poor quality products & $\begin{array}{c}0.230^{* * *} \\
(2.375)\end{array}$ & 1.108 \\
\hline Unsecured operations & $\begin{array}{c}0.097^{* * *} \\
(2.375)\end{array}$ & 1.127 \\
\hline Others & $\begin{array}{c}0.158^{* * *} \\
(4.029)\end{array}$ & 1.006 \\
\hline R squared & 0.581 & \\
\hline Adjusted R squared & 0.571 & \\
\hline R square change & 0.581 & \\
\hline Multiple R & 0.762 & \\
\hline No. of observations & 504 & \\
\hline
\end{tabular}

Source: Author's Fieldwork Survey Data 2014.

Notes: $1 . * * *$ indicates significance at the 0.05 level of significance.

2. Values in parentheses refer to $t$ statistic.

3. VIF refers to variance inflation factors as a measure of multicollineairty. 
Table 5 shows that all the coefficients got expected signs and are statistically significant at $5 \%$ level of significance. Like descriptive statistics, slow internet appears to be the dominant explanatory component of bad experiences face by Malaysian users of e-commerce and unsecured operations is the lowest explanatory factor for bad experiences. The overall fit of the model is about $57 \%$ which can be treated as moderate good fit model. The regression model estimated does not have any issue of collinearity as variance inflation factors (VIF) are far below than 10.00. Heteroskedasticity and JarqueBera (JB) tests also do not bring any suspicious results; and we did not perform autocorrelation test as the data set are not of time series in nature.

Next, the effects of demographic variables such as gender, race and level of income on the e-commerce experience were examined using one-way ANOVA. Table 6 depicts that with regards to different components of ecommerce experiences the mean values for males are higher than those of females and gender differences play a significant role in determining the factors that affect e-commerce experiences as all the F-ratios are statistically significant at least at 0.10 level of significance excepting for after purchase service. However, no conclusion, based on gender differences, can be drawn for the bad experience components. As can be viewed in Table 6, mean values for slow internet, slow delivery and unfriendly website of males are higher than females and the mean values for complicated payment method, poor quality products and unsecured operations of females are higher than males. This difference indicates that males perceive slow internet, slow delivery and unfriendly website more significant than females while females perceive complicated payment system, poor quality products and unsecured operations as more significant than males although these results are not all statistically significant except the factor slow delivery.

Table 6. Effects of Gender Differences on E-Commerce Experiences

\begin{tabular}{|l|c|c|c|c|c|c|}
\hline & \multicolumn{2}{|c|}{ Male } & \multicolumn{2}{c|}{ Female } & \multicolumn{2}{c|}{ F-test } \\
\hline Factor & Mean & SD & Mean & SD & F-ratio & F-sig. \\
\hline Overall quality & 3.57 & 0.71 & 3.32 & 0.89 & 11.66 & 0.001 \\
\hline Value & 3.53 & 0.78 & 3.28 & 0.80 & 11.25 & 0.001 \\
\hline Purchase experience & 3.52 & 0.77 & 3.37 & 0.92 & 3.26 & 0.07 \\
\hline Installation experience & 3.42 & 0.82 & 3.25 & 0.93 & 4.77 & 0.02 \\
\hline Usage experience & 3.55 & 0.79 & 3.30 & 0.91 & 10.30 & 0.001 \\
\hline After purchase service & 3.27 & 0.95 & 3.14 & 0.98 & 2.36 & 0.125 \\
\hline Bad experience components & & & & & & \\
\hline Slow internet & 0.36 & 0.48 & 0.33 & 0.47 & 0.50 & 0.47 \\
\hline Slow delivery & 0.34 & 0.47 & 0.21 & 0.40 & 10.74 & 0.001 \\
\hline Unfriendly website & 0.26 & 0.43 & 0.25 & 0.43 & 0.02 & 0.87 \\
\hline Complicated payment method & 0.16 & 0.36 & 0.21 & 0.41 & 2.25 & 0.13 \\
\hline Poor quality products & 0.17 & 0.38 & 0.23 & 0.42 & 2.16 & 0.14 \\
\hline Unsecured operations & 0.08 & 0.27 & 0.11 & 0.31 & 1.36 & 0.24 \\
\hline Others & 0.04 & 0.19 & 0.03 & 0.18 & 0.15 & 0.69 \\
\hline
\end{tabular}

Source: Author's Fieldwork Survey Data 2014. 
Table 7 reports that race differences significantly matter for all experience components except overall quality and purchase experiences because the values of F-statistic are statistically significant at the 0.10 level of significance. The mean values for Malays being higher than all other races indicate that Malays perceive significantly more satisfactions than other races. Like previous analysis, no conclusion about the effects of race differences on the bad experiences of e-commerce transaction can be drawn because none of the values of F-statistic are significant at the 0.10 level of significance.

Table 7. Effects of Race Differences on E-Commerce Experiences

\begin{tabular}{|c|c|c|c|c|c|c|c|c|c|c|}
\hline & \multicolumn{2}{|c|}{ Malay } & \multicolumn{2}{|c|}{ Indian } & \multicolumn{2}{|c|}{ Chinese } & \multicolumn{2}{|c|}{ Others } & \multicolumn{2}{|c|}{ F-test } \\
\hline Factor & Mean & $S D$ & Mean & $S D$ & Mean & $S D$ & Mean & $S D$ & $F$-ratio & $\begin{array}{l}F- \\
\text { sig. }\end{array}$ \\
\hline $\begin{array}{l}\text { Overall } \\
\text { quality }\end{array}$ & 3.45 & 0.79 & 3.10 & 0.96 & 3.27 & 1.48 & 3.33 & 0.72 & 1.76 & 0.15 \\
\hline Value & 3.42 & 0.76 & 3.35 & 0.93 & 2.93 & 1.03 & 3.30 & 0.85 & 2.13 & 0.09 \\
\hline $\begin{array}{l}\text { Purchase } \\
\text { experience }\end{array}$ & 3.48 & 0.86 & 3.25 & 0.96 & 3.20 & 1.37 & 3.30 & 0.77 & 1.81 & 0.14 \\
\hline $\begin{array}{l}\text { Installation } \\
\text { experience }\end{array}$ & 3.38 & 0.84 & 3.25 & 1.02 & 3.13 & 1.59 & 3.10 & 0.89 & 2.80 & 0.03 \\
\hline $\begin{array}{l}\text { Usage } \\
\text { experience }\end{array}$ & 3.46 & 0.81 & 3.35 & 1.08 & 2.73 & 1.48 & 3.28 & 0.87 & 4.27 & 0.00 \\
\hline $\begin{array}{l}\text { After } \\
\text { purchase } \\
\text { service } \\
\end{array}$ & 3.27 & 0.91 & 3.35 & 1.04 & 2.53 & 1.56 & 2.94 & 1.00 & 5.53 & 0.00 \\
\hline \multicolumn{11}{|c|}{ Bad experience components } \\
\hline Slow internet & 0.33 & 0.46 & 0.35 & 0.48 & 0.27 & 0.45 & 0.40 & 0.49 & 0.81 & 0.48 \\
\hline $\begin{array}{l}\text { Slow } \\
\text { delivery }\end{array}$ & 0.25 & 0.43 & 0.15 & 0.36 & 0.20 & 0.41 & 0.30 & 0.46 & 0.76 & 0.51 \\
\hline $\begin{array}{l}\text { Unfriendly } \\
\text { website }\end{array}$ & 0.24 & 0.43 & 0.30 & 0.47 & 0.27 & 0.45 & 0.29 & 0.45 & 0.33 & 0.80 \\
\hline $\begin{array}{l}\text { Complicated } \\
\text { payment } \\
\text { method }\end{array}$ & 0.20 & 0.40 & 0.20 & 0.41 & 0.13 & 0.35 & 0.15 & 0.35 & 0.61 & 0.60 \\
\hline $\begin{array}{l}\text { Poor quality } \\
\text { products }\end{array}$ & 0.21 & 0.40 & 0.25 & 0.44 & 0.33 & 0.48 & 0.18 & 0.38 & 0.68 & 0.56 \\
\hline $\begin{array}{l}\text { Unsecured } \\
\text { operations }\end{array}$ & 0.10 & 0.30 & 0.10 & 0.30 & 0.20 & 0.41 & 0.07 & 0.26 & 0.78 & 0.50 \\
\hline Others & 0.03 & 0.18 & 0.00 & 0.00 & 0.00 & 0.00 & 0.05 & 0.20 & 0.36 & 0.78 \\
\hline
\end{tabular}

Source: Author's Fieldwork Survey Data 2014.

The effect of income differences on the e-commerce experiences is shown in Table 8. It can be seen that level of income has significant effects on the satisfaction with e-commerce transaction except one exception, overall quality because all associated F-values are statistically significant at least at the 0.10 level of significance. For value component, the income owners of RM6000-RM7999 perceive more satisfaction than others as the mean value is higher for this group. The income group of RM4000-RM5999 is found to perceive more satisfaction than other income groups on the purchase, installation, usage, and after purchase experiences. However, none of the F-values are found to be statistically significant for the bad experience components excepting unsecured operations. 
Table 8. Effects of Income Differences on E-commerce

\begin{tabular}{|c|c|c|c|c|c|c|c|c|c|c|c|c|c|c|}
\hline \multirow[b]{2}{*}{ Factor } & \multicolumn{2}{|c|}{$<$ RM 2,000 } & \multicolumn{2}{|c|}{ RM 2,000-3,999 } & \multicolumn{2}{|c|}{ RM 4,000-5,999 } & \multicolumn{2}{|c|}{ RM 6,000-7,999 } & \multicolumn{2}{|c|}{ RM 8,000-9,999 } & \multicolumn{2}{|c|}{$>$ RM 10,000 } & \multicolumn{2}{|c|}{ F-test } \\
\hline & Mean & $S D$ & Mean & $S D$ & Mean & $S D$ & Mean & $S D$ & Mean & $S D$ & Mean & $S D$ & $\begin{array}{c}F- \\
\text { ratio }\end{array}$ & $F$-sig. \\
\hline Overall quality & 3.43 & 0.73 & 3.42 & 0.88 & 3.67 & 0.81 & 3.50 & 0.79 & 3.50 & 1.36 & 3.13 & 0.64 & 0.67 & 0.64 \\
\hline Value & 3.43 & 0.73 & 3.30 & 0.88 & 3.67 & 0.91 & 3.75 & 0.62 & 3.19 & 0.98 & 3.00 & 0.75 & 2.04 & 0.07 \\
\hline $\begin{array}{l}\text { Purchase } \\
\text { experience }\end{array}$ & 3.52 & 0.79 & 3.34 & 0.92 & 3.83 & 0.70 & 3.33 & 0.77 & 3.00 & 1.09 & 3.00 & 1.19 & 3.14 & 0.00 \\
\hline $\begin{array}{l}\text { Installation } \\
\text { experience }\end{array}$ & 3.39 & 0.79 & 3.26 & 0.99 & 3.75 & 0.84 & 3.67 & 0.98 & 2.56 & 1.31 & 3.25 & 0.70 & 4.28 & 0.00 \\
\hline $\begin{array}{l}\text { Usage } \\
\text { experience }\end{array}$ & 3.49 & 0.78 & 3.23 & 0.94 & 3.92 & 0.77 & 3.25 & 0.96 & 2.94 & 1.28 & 3.13 & 0.64 & 4.33 & 0.00 \\
\hline $\begin{array}{l}\text { After purchase } \\
\text { service }\end{array}$ & 3.21 & 0.95 & 3.10 & 1.00 & 3.63 & 1.01 & 3.17 & 1.03 & 2.69 & 1.40 & 3.00 & 0.53 & 2.04 & 0.07 \\
\hline \multicolumn{15}{|c|}{ Bad experience components } \\
\hline Slow internet & 0.34 & 0.47 & 0.35 & 0.47 & 0.38 & 0.49 & 0.25 & 0.45 & 0.38 & 0.50 & 0.50 & 0.53 & 0.29 & 0.91 \\
\hline Slow delivery & 0.27 & 0.44 & 0.21 & 0.41 & 0.21 & 0.41 & 0.25 & 0.45 & 0.44 & 0.51 & 0.25 & 0.46 & 0.86 & 0.50 \\
\hline $\begin{array}{l}\text { Unfriendly } \\
\text { website }\end{array}$ & 0.28 & 0.44 & 0.24 & 0.43 & 0.17 & 0.38 & 0.33 & 0.49 & 0.44 & 0.51 & 0.25 & 0.46 & 0.85 & 0.51 \\
\hline $\begin{array}{l}\text { Complicated } \\
\text { payment method }\end{array}$ & 0.18 & 0.38 & 0.17 & 0.38 & 0.25 & 0.44 & 0.08 & 0.28 & 0.31 & 0.47 & 0.00 & 0.00 & 1.02 & 0.40 \\
\hline $\begin{array}{l}\text { Poor quality } \\
\text { products }\end{array}$ & 0.18 & 0.38 & 0.18 & 0.39 & 0.21 & 0.41 & 0.25 & 0.45 & 0.31 & 0.47 & 0.38 & 0.51 & 0.74 & 0.59 \\
\hline $\begin{array}{l}\text { Unsecured } \\
\text { operations }\end{array}$ & 0.11 & 0.31 & 0.09 & 0.28 & 0.00 & 0.00 & 0.00 & 0.00 & 0.44 & 0.11 & 0.46 & 0.16 & 2.05 & 0.07 \\
\hline Others & 0.02 & 0.14 & 0.05 & 0.22 & 0.13 & 0.35 & 0.00 & 0.00 & 0.00 & 0.00 & 0.17 & 0.40 & 1.44 & 0.20 \\
\hline
\end{tabular}

Source: Author's Fieldwork Survey Data 2014. 


\section{Implications and Contributions}

The findings of this study provide insights to the policymakers and small and medium business practitioners. The issue of after purchase service and slow internet, as discussed by Mathwick et al. (2001), should be given priority in the e-commerce policies to make the small and medium businesses friendlier to the e-commerce users. Emphasis should also be given to demographic profiles of e-commerce users for adopting online services when policy issues arise. Small businesses should enhance their after purchase services to make the e-commerce customers comfortable and return back to the products in the next time. The small business websites should be designed in such a way so that speedy transactions can be made. They should also focus on the tailor made facilities based on the demographic profiles of the customers as emphasized by Dillon and Reif (2004).

The main contribution of this study is to add to the dearth literature of the users' perceptions of e-commerce study in the context of Malaysia in general and in particular to the study of e-commerce experiences and challenges. This study revisits the bad experiences face by Malaysian customers and interestingly identified that security or unsecured operation in e-commerce transaction is no longer a serious issue to Malaysian customers although it was on the top of the list in the studies conducted in the last decade (Alam et al. 2008, Khatibi et al. 2003, Lallmahamood 2007, Mukti 2000, Paynter and Lim 2001). The burning issue for the customers today is slow internet followed by slow delivery of the products, poor quality products, complicated method of payments and unfriendly website.

\section{Conclusions}

The objective of this study was to identify the challenges of Malaysian users in using e-commerce facilities provided by the small businesses by applying statistical procedures including descriptive statistics, multiple regressions and one way ANOVA. Questions were asked about overall experiences of using e-commerce facilities and it was revealed that customers are more concerned with after purchase services for the products they buy using the web pages of small businesses followed by overall quality of the eservice, usage experiences and installation. In response to the bad experiences the users are more concerned with slow internet followed by slow delivery of the products, unfriendly website, poor quality products, complicated payment system, and unsecured operations. It is evident from the results of the study that although security and privacy appeared most important barrier of the ecommerce adoption in many previous studies in the last decades, it is not a big challenge for the Malaysian users. The study provides new insights for the policymakers and practitioners to focus on the issues like improving after purchase deliveries, improving internet speed, updating website quality and ease payment systems. 


\section{References}

Abbad M, Abbad R, Saleh, M (2011) Limitations of e-commerce in developing countries: Jordan case. Education, Business and Society: Contemporary Middle Eastern Issues 4(4): 280-291.

Aladwani AM, Palvia, PC (2002) Developing and validating an instrument for measuring user-perceived web quality. Information and Management 39(6): 467476.

Alam SS, Khatibi A, Ahmad MIS, Ismail HB (2008) Factors affecting e-commerce adoption in the electronic manufacturing companies in Malaysia. International Journal of Commerce and Management 17(1/2): 125-139.

Bauer C, Scharl A (2000) Quantitive evaluation of Web site content and structure. Internet Research 10(1): 31-44.

Corbitt BJ, Thanasankit T, Yi H (2003) Trust and e-commerce: a study of consumer perceptions. Electronic Commerce Research and Applications 2(3): 203-215.

Dabholkar PA (1996) Consumer evaluations of new technology-based self-service options: an investigation of alternative models of service quality. International Journal of Research in Marketing 13(1): 29-51.

Dillon TW, Reif HL (2004) Factors influencing consumers e-commerce commodity purchases. Information Technology, Learning and Performance Journal 22(2).

Goldstein A, O'connor D (2000) E-commerce for Development: Prospects and Policy Issues. 94. Paris: OECD Development Centre.

Internet World Stats (2014) Usage and Population Statistics. Available at: http://bit.ly/1yjeLzL.

Khatibi A, Thyagarajan V, Seetharaman A (2003) E-commerce in Malaysia: perceived benefits and barriers. Vikalpa 28(3): 77-82.

Lallmahamood M (2007) An Examination of Individual's Perceived Security and Privacy of the Internet in Malaysia and the Influence of this on their Intention to Use E-commerce: Using an Extension of the Technology Acceptance Model. Malaysian Institute of Management.

Liao C, Palvia P, Lin H-N (2006) The roles of habit and web site quality in ecommerce. International Journal of Information Management 26(6): 469-483.

Lin H-F (2007) The impact of website quality dimensions on customer satisfaction in the B2C e-commerce context. Total Quality Management and Business Excellence 18(4): 363-378.

Liu C, Arnett KP (2002) An examination of privacy policies in Fortune $500 \mathrm{Web}$ sites. American Journal of Business 17(1): 13-22.

Loiacono ET, Watson RT, Goodhue DL (2002) WEBQUAL: a measure of website quality. Marketing Theory and Applications 13(3): 432-438.

Mathwick C, Malhotra N, Rigdon E (2001) Experiential value: conceptualization, measurement and application in the catalog and Internet shopping environment. Journal of Retailing 77(1): 39-56.

Meuter ML, Ostrom AL, Roundtree RI, Bitner MJ (2000) Self-service technologies: understanding customer satisfaction with technology-based service encounters. Journal of Marketing 64(3): 50-64.

Mukti NA (2000) Barriers to putting businesses on the Internet in Malaysia. The Electronic Journal of Information Systems in Developing Countries 2.

Olsina L, Lafuente G, Rossi G (2001) Specifying quality characteristics and attributes for websites. In Web Engineering: Springer: 266-278. 
Paynter J, Lim J (2001) Drivers and impediments to e-commerce in Malaysia. Malaysian Journal of Library and Information Science 6(2): 1-19.

Potter M (1994) International business benchmarking. Management Services 38(10): 6-8.

Ranganathan C, Ganapathy S (2002) Key dimensions of business-to-consumer web sites. Information and Management 39(6): 457-465.

Santos J (2003) E-service quality: a model of virtual service quality dimensions. Managing Service Quality 13(3): 233-246.

Shah Alam S, Ali MY, Mohd Jani MF (2011) An empirical study of factors affecting electronic commerce adoption among SMEs in Malaysia. Journal of Business Economics and Management 12(2): 375-399.

Turban E, Lee JK, King D, Liang TP, Turban D (2009) Electronic Commerce 2010. Prentice Hall Press.

Udo GJ (2001) Privacy and security concerns as major barriers for e-commerce: a survey study. Information Management and Computer Security 9(4): 165-174.

Van Slyke C, Belanger F, Haynes J (2003) The Impact of Interface Complexity on Elderly Users: An Extension of the Technology Acceptance Model. Savannah, GA: SAIS.

Wang M (2003) Assessment of e-service quality via e-satisfaction in e-commerce globalization. EJISDC: The Electronic Journal on Information Systems in Developing Countries (11): 1-4.

Zeithaml VA, Berry LL, Parasuraman A (1996) The behavioral consequences of service quality. Journal of Marketing 60(2). 